\section{Neuropsychobiology}

Neuropsychobiology 1998;38:181-184

\section{J. Walden $^{\text {a }}$ \\ C. Normann ${ }^{\text {a }}$ \\ J. Langosch ${ }^{\mathrm{a}}$ \\ M. Berger ${ }^{\mathrm{a}}$ \\ H. Grunze}

Departments of Psychiatry,

Universities of

${ }^{\text {a }}$ Freiburg and

${ }^{\mathrm{b}}$ Munich, Germany

\title{
Differential Treatment of Bipolar Disorder with Old and New Antiepileptic Drugs
}

\section{Key Words \\ Pure mania \\ Mixed mania \\ Rapid cycling \\ Lamotrigine \\ Gabapentin}

\begin{abstract}
Although lithium remains the preferred medication for bipolar disorders, new investigations suggest that only 60 to $80 \%$ of patients have a good response with a classical presentation. The antiepileptics carbamazepine and valproate are important alternatives. Several studies have shown that lithium, carbamazepine and valproate are effective in pure mania. Mixed mania and rapid cycling respond, however, well to valproate. One disadvantage of carbamazepine is its enzyme inducing property with the consequence of a decrease of plasma levels of other psychotropic medications and a worsening of psychopathology. First data indicate a good antimanic and antidepressive efficacy of the new antiepileptic drug lamotrigine.
\end{abstract}

\section{Introduction}

There is now substantial evidence that the mood stabilizers lithium, carbamazepine and valproate are effective in the treatment of acute episodes of mania. Less study data exist for the efficacy of these mood stabilizers in the management of bipolar (and unipolar) depression and in the prophylaxis of depressive phases [1-4]. The knowledge of several predictors of response for the different mood stabilizers would improve the total treatment response and eventually shorten the duration of hospitalization for the patients [5].

\section{Pure Mania vs. Mixed Mania}

Pure (or euphoric or typical) mania is characterized by typical manic symptoms without depressive features, e.g. elevated mood, grandiosity, reduced sleep time and increased activity. Approximately $40-60 \%$ of manic patients suffer from this type of mania. Up to $50 \%$ of bipolar patients, however, have mixed (or dysphoric mania) which is defined as an episode meeting the criteria both for mania and for a major depressive phase. Several investigations indicate that lithium, carbamazepine and valproate are effective in pure mania. On the other hand, these results also establish that mixed mania responds well to valproate whereas lithium is relatively ineffective in mixed mania [1, 6-8] (table 1).

A recently completed study from the European valproate acute mania study group [9] corroborates the results of the other cited studies. The aim of that investigation was to show that valproate-treated patients need less neuroleptics than placebo-treated patients. 136 patients were enrolled in this multicenter, randomized, double-blind, placebo-controlled parallel group study. As a result the mean daily dose of concomitant neuroleptic medication expressed as mg haloperidol equivalents continuously de-

\begin{tabular}{ll}
\hline KARGER & C1998 S. Karger AG, Basel \\
0302-242X/98/0383-0181\$15.00/0 \\
$\begin{array}{l}\text { Fax +41 61 306 1234 } \\
\begin{array}{l}\text { E-Mail karger@karger.ch } \\
\text { www.karger.com }\end{array}\end{array}$ & $\begin{array}{l}\text { Accessible online at: } \\
\text { http://BioMedNet.com/karger }\end{array}$
\end{tabular}

Prof. Dr. Dr. Jörg Walden
Department of Psychiatry, University of Freiburg
Hauptstr. 5, D-79104 Freiburg (Germany)
Tel. + 49 (0)761/2706601, Fax + 49 (0)761/2706619 
Table 1. Predictors of good response to valproate

\begin{tabular}{|c|c|c|}
\hline \multirow[t]{5}{*}{ Mixed mania } & Himmelhoch et al. (1976) & $\begin{array}{l}41 \% \text { moderate or better response for lithium in mixed mania } \\
\text { vs. } 81 \% \text { in pure mania }\end{array}$ \\
\hline & Secunda et al. (1985) & $\begin{array}{l}29 \% \text { moderate or better response for lithium in mixed mania } \\
\text { vs. } 91 \% \text { in pure mania }\end{array}$ \\
\hline & Prien et al. (1988) & $\begin{array}{l}36 \% \text { moderate or better response for lithium in mixed mania } \\
\text { vs. } 59 \% \text { in pure mania }\end{array}$ \\
\hline & $\begin{array}{l}\text { Müller-Oerlinghausen et al. } \\
\text { and European valproate acute } \\
\text { mania study group (1997) }\end{array}$ & $\begin{array}{l}\text { decrease of haloperidol equivalents in the total } \\
\text { valproate group from } 14.3 \text { to } 8.1 \mathrm{mg} \text { and for dysphoria item } \\
\text { from } 13.9 \text { to } 5.8 \mathrm{mg}\end{array}$ \\
\hline & Swann et al. (1997) & $\begin{array}{l}\text { a depressive presentation was associated with a poorer } \\
\text { response to lithium in several scales (SADS) }\end{array}$ \\
\hline \multirow[t]{3}{*}{ Rapid cycling } & Dunner and Fieve (1974) & $\begin{array}{l}82 \% \text { of rapid cyclers were Li-resistant vs. } 41 \% \text { in the group } \\
\text { of classical mania }\end{array}$ \\
\hline & Kukopulos et al. (1980) & open longitudinal study; $72 \%$ show low efficacy to lithium \\
\hline & Calabrese et al. (1993) & $\begin{array}{l}101 \text { patients with rapid cycling: marked acute and } \\
\text { prophylactic antimanic effects, marked antimixed } \\
\text { state effects and poor-to-moderate acute and prophylactic } \\
\text { antidepressant effects }\end{array}$ \\
\hline
\end{tabular}

creased in the valproate group from $14.3 \mathrm{mg}$ at the beginning of the study to $8.1 \mathrm{mg}$ after 3 weeks. In the placebo group the decline was from $12.0 \mathrm{mg}$ to $10.8 \mathrm{mg}$ (the difference was statistically significant, $\mathrm{p}=0.0001$; fig. 1 ). Patients scoring high for the dysphoria item (item 5) of the Young mania rating scale had an even more favorable outcome with valproate, with a decrease of the daily haloperidol equivalents from 13.9 at the beginning to 6.1 at the end of the study.

Another new parallel-group, double-blind study with 179 patients indicates that depressive symptoms during a manic episode were associated with a poor antimanic response to lithium and with a better response to valproate [11]. The authors conclude that even a modest level of pretreatment depression-related symptoms is a robust predictor of lithium nonresponse and is associated with a better response to valproate. Data concerning carbamazepine in pure or mixed mania are less clear because many of the clinical studies were not double blind or randomized which limits its interpretability [10].

A major disadvantage of carbamazepine is, however, its enzyme-inducing properties with the consequence that its own plasma levels (autoinduction) as well as plasma levels of concomitant psychotropic medication (heteroinduction) may decrease. In a recent controlled clinical trial with 30 patients with schizophrenia or schizoaffective disorder three different groups were randomly assigned to 4 weeks of treatment with either haloperidol alone, haloperidol with carbamazepine or with haloperidol with valproate $[12,13]$. As a result the use of carbamazepine was associated with significant lower haloperidol plasma levels and a worse clinical outcome (pPANSS-Score) compared to antipsychotic monotherapy (fig. 2). Valproate had no significant effect on the plasma level and did not influence the psychopathology.

\section{Rapid Cycling}

Four or more depressive or manic phases in 1 year has been defined as rapid cycling bipolar disorder. It is assumed that $13-20 \%$ of bipolar patients have rapid cycling [16]. In general, patients with bipolar rapid cycling have a lower response rate to lithium during both acute and prophylactic treatment $[14,15]$. In an open longitudinal study with 434 patients $72 \%$ showed a low efficacy of lithium treatment [17].

Studies are not consistent concerning the efficacy of carbamazepine in rapid cycling [18, 19]. A metaanalyis shows, however, that the response rate for carbamazepine is $32 \%$ for depression and $52 \%$ for mania which is worse than the efficacy in a prospective study indicating a good effect for valproate in $42 \%$ of depressed and $73 \%$ of manic patients [16]. In summary, rapid cycling seems to be a likely predictor of less response to lithium and possibly carbamazepine compared to valproate.

A special problem is a possible drug-induced switching from bipolar depression into mania. Whereas there are some discussions concerning a drug-induced switch into 


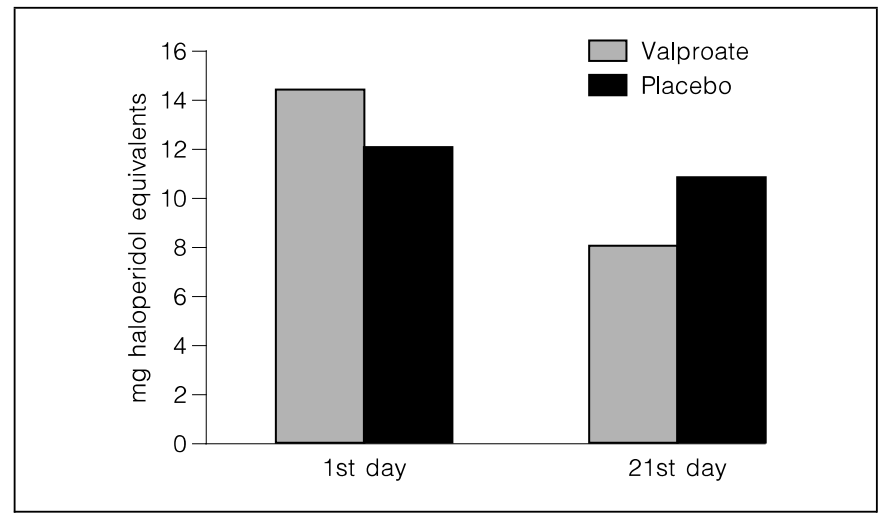

Fig. 1. Decrease of the mean daily dose of haloperidol equivalents in the valproate group and the placebo group. According to MüllerOerlinghausen and Retzow and the European valproate acute mania study group (1997) [9].

mania some hints in the literature indicate a cycle acceleration by the usage of antidepressant drugs [20].

In summary, the studies so far suggest that valproate is useful in a broad spectrum of bipolar disorders and is equally effective in pure mania as well as in mixed mania and rapid cycling. Furthermore, all atypical types of mania, e.g. mixed mania, rapid cycling, neurological cofactors and organic mania, respond less well to lithium. A major advantage of valproate is the fact that the drug is well tolerated in an effective plasma level range from 50 to $125 \mu \mathrm{g} / \mathrm{ml}$ [21]. Moreover, a dose loading with initial oral doses of $20 \mathrm{mg} / \mathrm{kg}$ body weight has shown a rapid clinical improvement of psychopathology [22].

\section{Lamotrigine and Gabapentin}

Several open studies suggest an efficacy of the new antiepileptic drug lamotrigine not only in the treatment of mania but also in depressed states in bipolar patients $[23,24]$. Controlled double-blind studies are still ongoing. Concerning long-term prophylactic efficacy, an interesting case of a patient with bipolar rapid cycling with valproate treatment reveals a drastic improvement after the addition of lamotrigine [24]. In this case lamotrigine up to $150 \mathrm{mg} /$ day was added to valproate $(2,700 \mathrm{mg} / \mathrm{day})$. A considerable improvement of the patient's condition was achieved several days after the beginning of lamotrigine coadministration and lasted over the total followup period of more than 1 year. There is also increasing evidence of the prophylactic efficacy of lamotrigine monotherapy in bipolar disorder with or without rapid cycling.

Differential Treatment of Bipolar Disorder with Old and New Antiepileptic Drugs

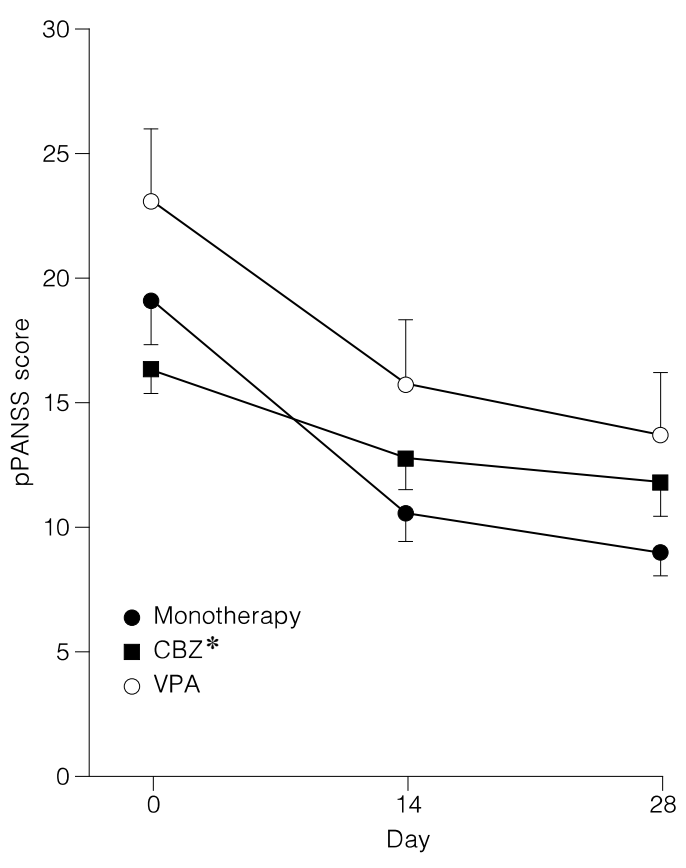

Fig. 2. Mean rating scores of the positive subscale of the PANSS in the haloperidol monotherapy group, the haloperidol + carbamazepine group (CBZ) and the haloperidol + valproate group (VPA). According to Normann et al. [13].

Furthermore, lamotrigine also appears to be valuable in the prophylaxis of schizoaffective disorders [Erfurth et al., this issue].

Moreover, recent single case reports suggest that gabapentin might also be useful in the treatment of mania. In an open trial we treated 14 patients with acute mania with gabapentin in a dose range from 1,200 to 4,800 $\mathrm{mg} /$ day [25]. Six patients received gabapentin as add-on medication and 8 were treated with gabapentin alone. As a result, gabapentin was both effective and safe when administered in combination with other drugs as lithium or valproate. BRMAS scores decreased from 37.7 to 7.8 on day 21 in the add-on group and from 27.8 to 9.0 in the monotherapy group. Four of 8 patients in the monotherapy group dropped out due to a failure of efficacy. As these were the patients with the highest BRMAS scores, it can be assumed that gabapentin might be useful in patients with modest but not severe mania.

\section{Aknowledgement}

The authors acknowledge support of the Theodore and Vada Stanley Foundation. 


\section{References}

1 Bowden C: Predictors of response to divalproex and lithium. J Clin Psychiatry 1995;56(suppl 3): 25-30.

2 Bowden CL, Brugger AM, Swann AC, Calabrese J: Efficacy of divalproex vs lithium and placebo in the treatment of mania. JAMA 1994; 271:918-924.

3 Freeman TW, Clothier J, Pazzaglia P: A double blind comparison of valproate and lithium in the treatment of acute mania. Am J Psychiatry 1992;149:108-111.

4 Pope HG, McElroy S, Keck P: Valproate in the treatment of acute mania: A placebo controlled study. Arch Gen Psychiatry 1991;48:62-68.

5 Frye MA, Altshuler LL, Szuba MP: The relationship between antimanic agent for treatment of classic or dysphoric mania and length of hospital stay. J Clin Psychiatry 1996;57:17-21.

6 Himmelhoch J, Mulla D, Neil JF: Incidence and significance of mixed affective states in a bipolar population. Arch Gen Psychiatry 1976;33:1062 1066.

7 Secunda SK, Katz MM, Swann AC: Mania: Diagnosis, state measurement and prediction of treatment response. J Affect Disorders 1985;8: 113-121.

8 Prien RF, Himmelhoch JM, Kupfer DJ: Treatment of mixed mania. J Affect Disorders 1988; 15:9-15.

9 Müller-Oerlinghausen B, Retzow A: Valproate as adjunct to neuroleptic medication in the treatment of acute episodes of mania. Pharmacopsychiatry 1997;30:202.
10 Ballenger JC, Post R: Carbamazepine in manicdepressive illness: A new treatment. Am J Psychiatry 1980;137:782-790.

11 Swann AC, Bowden CL, Morris D, Calabrese J, Petty F, Small J, Dilsalver SC, Davis JM: Depression during mania: Treatment response to lithium or divalproex. Arch Gen Psychiatry 1997:54:37-42.

12 Hesslinger B, Normann C, Langosch J, Klose P, Berger M, Walden J: Effects of carbamazepine and valproate on haloperidol plasma levels and psychopathological outcome in schizophrenic patients. J Clin Psychopharmacol 1998;submitted.

13 Normann C, Klose P, Hesslinger B, Langosch J, Berger M, Walden J: Haloperidol plasma levels and psychopathology in schizophrenic patients with antiepileptic co-medication: A clinical trial. Pharmacopsychiatry 1997;30:204.

14 Dunner DL, Fieve RR: Clinical factors in lithium carbonate prophylaxis failure. Arch Gen Psychiatry 1974;30:229-233.

15 Calabrese J, Delucci G: Spectrum of efficacy of valproate in 55 patients with rapid cycling bipolar disorder. Am J Psychiatry 1990;147: 431-434.

16 Calabrese JR, Woyshville MJ, Kimmel SE, Rapport DJ: Predictors of valproate response in bipolar rapid cycling. J Clin Psychopharmacol 1993;13:280-283.

17 Kukopulos A, Reginaldi D, Laddomada P, Floric G, Serra G, Tondo L: Course of the manic depressive cycle and changes caused by treatment. Pharmacopsychiatry 1980;13:156-167.
18 Post R, Rubinow DR, Uhde T: Dysphoric mania: Clinical and biological correlates. Arch Gen Psychiatry 1989;46:353-358.

19 Dilsaver SC, Swann AC, Shoaib AM: The manic syndrome: Factors which may predict a patient's response to lithium, carbamazepine and valproate. J Psychiatry Neurosci 1993;18:61-66.

20 Altshuler L, Post R, Leverich GS, Mikalauskas K, Rosoff A, Ackermann BA: Antidepressant induced mania and cycle acceleration: A controversy revisited. Am J Psychiatry 1995;152:1130 1138.

21 VanValkenburg C, Kluznik J, Merill R, Erickson W: Therapeutic levels of valproate for psychosis. Psychopharmacol Bull 1990;26:254-255.

22 Keck P, McElroy SL, Tugrul K: Valproate loading in the treatment of acute mania. J Clin Psychiatry 1993;54:305-308.

23 Fatemi SH, Rapport DJ, Calabrese J, Thuras P: Lamotrigine in rapid cycling bipolar disorder. J Clin Psychiatry 1997;58:522-527.

24 Walden J, Hesslinger B, van Calker D, Berger M: Addition of lamotrigine to valproate may enhance efficacy in the treatment of bipolar affective disorder. Pharmacopsychiatry 1996;29: 193-195.

25 Erfurth A, Kammerer C, Grunze H, Normann C, Walden J: An open label study of gabapentin in the treatment of acute mania. J Psychiatr Res 1998 ;in press 